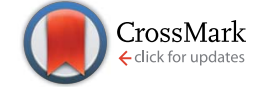

Cite this: RSC Adv., 2017, 7, 3928

\title{
Molecular diversity from the three-component reaction of 2-hydroxy-1,4-naphthaquinone, aldehydes and 6-aminouracils: a reaction condition dependent MCR $\dagger$
}

\author{
Ruchi Bharti, ${ }^{a}$ Pooja Kumari, ${ }^{a}$ Tasneem Parvin*a and Lokman H. Choudhury ${ }^{\star b}$
}

The three-component reaction of 2-hydroxy-1,4-naphthaquinone, aldehydes, and 6-aminouracil derivatives in acetic acid/water $(1: 1 ; \mathrm{v} / \mathrm{v})$ under microwave heating conditions provides 1,4-dihydropyridines fused with naphthaquinone and pyrimidines. On the other hand the same reaction combinations under conventional reflux conditions provide acyclic trisubstituted methane derivatives. Using these tuneable reaction conditions a series of polycyclic fused $\mathrm{N}$-heterocycles has been synthesized. The notable features of this methodology are a simple metal-free one-pot operation, easy purification process, use of the green solvent water, short reaction time and good to moderate yields of the products.

Received 25th July 2016

Accepted 12th December 2016

DOI: $10.1039 / c 6 r a 18828 a$

www.rsc.org/advances

\section{Introduction}

One-pot multicomponent reactions (MCRs) have emerged as an efficient tool for benign synthesis of functionalized heterocycles by virtue of their convergence, productivity, facile execution, and generation of highly diverse and complex products from easily available starting materials in a single operation. ${ }^{1}$ MCRs are very useful to access "privileged medicinal scaffolds", especially, for synthesizing various N-heterocyclic compounds which are key constituents of a wide range of both natural and synthetic bioactive compounds., ${ }^{2,3}$ Microwave assisted multicomponent reactions have drawn remarkable attention from organic and medicinal chemists considering their green features. MW irradiation provides enhanced reaction rates, higher yields of products, better selectivity, rapid optimization of reactions and several ecofriendly advantages. ${ }^{4}$ Further, in comparison with organic solvents, water is a non-toxic, noncorrosive, non-explosive and is readily available solvent. These properties along with the network of hydrogen bonds, large surface tension, high polarity and high specific heat capacity make it both economical and environmentally friendly and thus suitable as a green solvent. ${ }^{5,6}$ According to the current synthetic requirements and from green perspective, environmentally benign multicomponent procedures employing microwave methodology in aqueous medium are particularly welcome.

${ }^{a}$ Department of Chemistry, National Institute of Technology Patna, Ashok Rajpath, Patna-800 005, Bihar, India. E-mail: tasneem@nitp.ac.in

${ }^{b}$ Department of Chemistry, Indian Institute of Technology Patna, Bihta, Patna-801103, Bihar, India.E-mail: lokman@iitp.ac.in

$\dagger$ Electronic supplementary information (ESI) available: General experimental procedure, characterization data, with copies of ${ }^{1} \mathrm{H},{ }^{13} \mathrm{C}$ NMR spectrum. See DOI: $10.1039 / \mathrm{c} 6 \mathrm{ra} 18828 \mathrm{a}$
Polycyclic fused N-heterocycles have attracted much attention due to their presence in biologically active natural products and pharmaceuticals. They display a wide range of biological activities such as antifungal, antibacterial, antineoplastic, anticancer, antiplasmodial, and as DNA intercalators. ${ }^{7}$ The presence of several functional groups in one molecule often proves useful to find better bioactivities of compounds. Further, literature survey shows that fused polycyclic N-heterocycles containing naphthaquinone, ${ }^{8-10}$ 1,4-dihydro pyridine ${ }^{11-13}$ and pyrimidine $\mathrm{e}^{14}$ moieties are important in discovering new bioactive compounds due to their fascinating molecular structure and remarkable pharmacological efficiency. This class of building blocks are useful for treating Alzheimer's disease ${ }^{15}$ and also exhibit anti-tumor, ${ }^{16}$ antimicrobial, ${ }^{17}$ anti-diarrhea, ${ }^{18}$ and

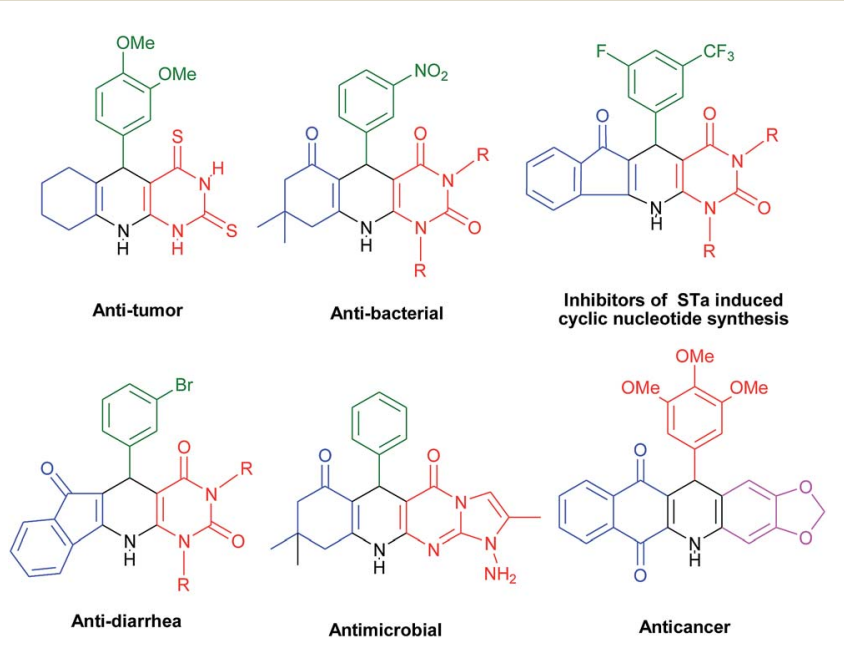

Fig. 1 Examples of pharmaceutically important fused polycyclic Nheterocycles and their activities. 


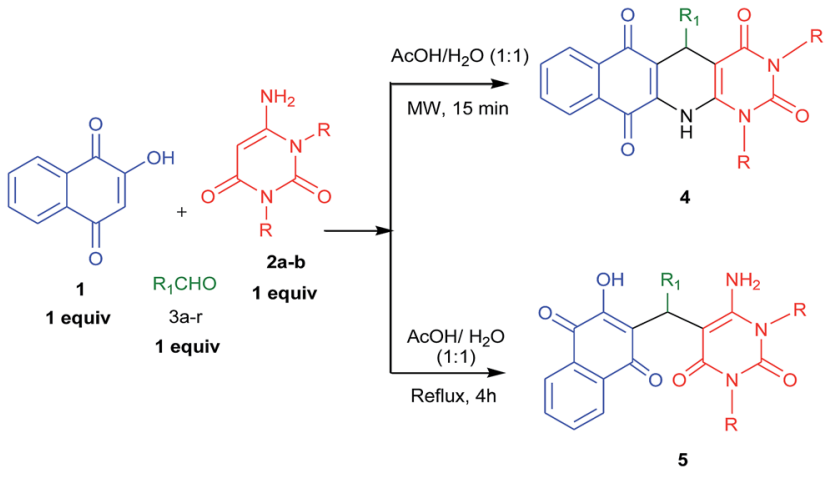

Scheme 1 Formation of 4 and 5 in different reaction conditions from the three component reactions.

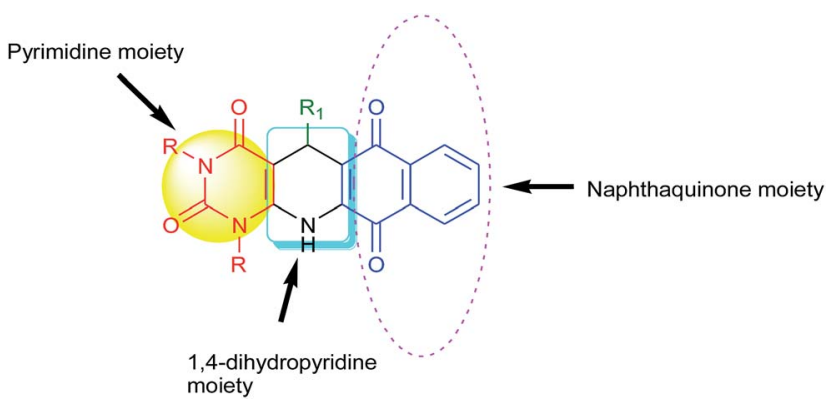

Fig. 2 Product having three important bioactive moieties.

anti-cancer activities. ${ }^{19}$ Some of the pharmacologically active fused polycyclic N-heterocycles are shown in Fig. 1.

6-Aminouracil is considered as a very popular and useful starting material for the synthesis of heterocyclic scaffolds using multicomponent reaction. ${ }^{20}$ Recently various research groups have explored 6-amino uracil in multicomponent reactions to construct fused heterocycles. ${ }^{21}$

Considering the importance of fused polycyclic Nheterocycles having naphthaquinone, 1,4-DHP and pyrimidine moieties in pharmaceutical and chemical domains, and also as a part of our continuous effort on the synthesis of highly functionalized or fused heterocycles, ${ }^{22-24}$ we turned our attention to design a thee component reaction of 2-hydroxy-1,4naphthaquinone (1), 6-aminouracils (2) and aldehydes (3). In acetic acid/water $(1: 1)$ under reflux conditions we ended with acyclic products 5 (Scheme 1). Interestingly, when we carried out the same reaction under microwaves in acetic acid/water $(1: 1)$, we ended with fused polycyclic N-heterocycles 4 (Scheme 1). It consists of three important bioactive moieties naphthaquinone, 1,4-dihydropyridine and pyrimidine (Fig. 2).

\section{Results and discussion}

For the preliminary investigation, reaction of 2-hydroxy1,4-naphthaquinone 1, 1,3-dimethyl-6-aminouracil 2a and 4methyl benzaldehyde $3 \mathbf{c}$ was chosen as model reaction. In the presence of acetic acid under the reflux conditions, this combination provided $75 \%$ of acyclic product 5 ac within $5 \mathrm{~h}$ (Table 1, entry 1) and we did not get our desired three component cyclic product 4ac under this reaction conditions. Next, we attempted to get the cyclized product by varying various parameters of the reaction, such as using microwave heating, solvent etc. Interestingly, the same model reaction provided $77 \%$ yield of the corresponding fused polycyclic N-heterocyclic product $4 \mathrm{ac}$ and $12 \%$ of acyclic product $\mathbf{5 a c}$, after microwave heating at $130^{\circ} \mathrm{C}$ for 15 minutes in acetic acid medium (Table 1 , entry 2). The product $4 \mathbf{a c}$ was fully characterized by recording

Table 1 Optimization of reaction conditions ${ }^{a}$

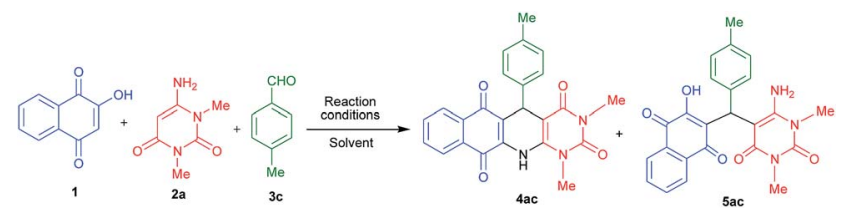

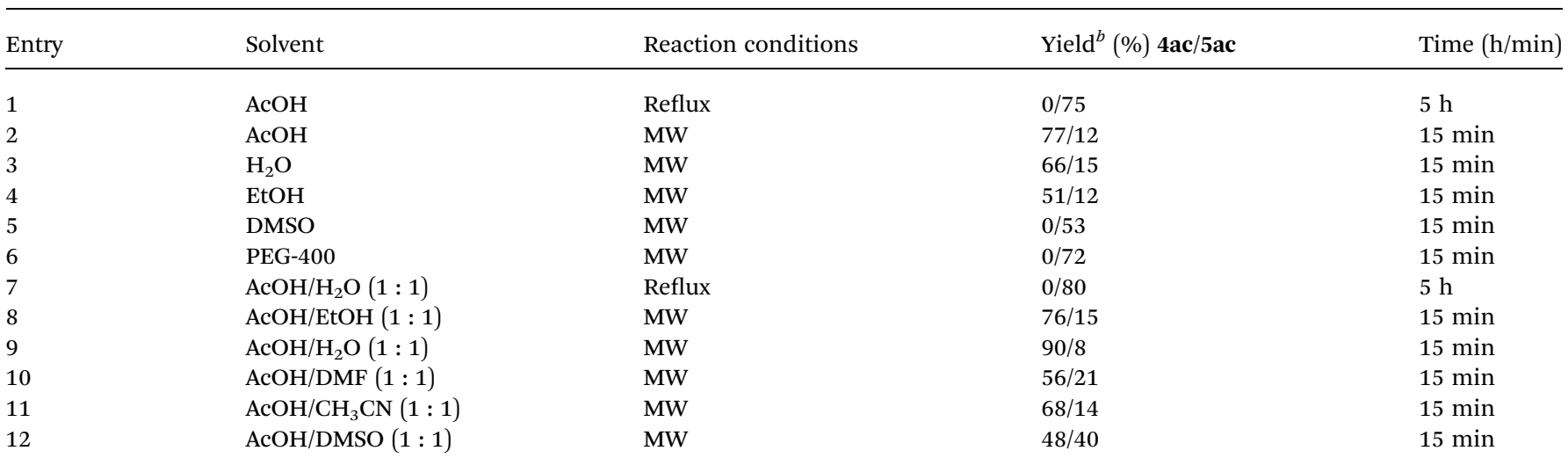

${ }^{a}$ Reactions were carried out in $1.0 \mathrm{mmol}$ scale with $1: 1: 1$ ratio of 2-hydroxy-1,4-naphthaquinone, 1,3-dimethyl-6-aminouracil and 4-methyl benzaldehyde in $2 \mathrm{ml}$ solvent. ${ }^{b}$ Isolated yields. 
IR, ${ }^{1} \mathrm{H} \&{ }^{13} \mathrm{C}$ NMR as well as HRMS. Encouraged by this positive result, the same set of reaction was performed in various solvents under microwave heating and the results are summarized in Table 1 (entries 3-6). Interestingly, it has been observed that when the reaction was performed in the presence of protic solvents like $\mathrm{AcOH}, \mathrm{H}_{2} \mathrm{O}$, and $\mathrm{EtOH}$ it gives cyclic product 4 ac as major and acyclic product 5ac as minor product (Table 1 entries $2-4)$. But when the reaction was performed in DMSO and PEG400 , only acyclic product 5ac was observed (Table 1, entries 5 and 6). To further investigate, we also performed the same model reaction using mixed solvent like acetic acid and other solvent $(1: 1)$ under reflux as well as microwave reaction conditions (Table 1, entries 7-12). Among them, acetic acid/ water $(1: 1)$ under microwave heating was found as optimum reaction conditions in terms of yield obtained (Table 1 , entry 9 ).

In order to explore the scope of this multicomponent reaction, a wide variety of aldehydes 3a-r were reacted with 2hydroxy-1,4-naphthaquinone $\mathbf{1}$ and aminouracil derivatives $\mathbf{2 a -}$ b under the optimized reaction conditions and the results are

Table 2 Scope of the reaction ${ }^{a}$

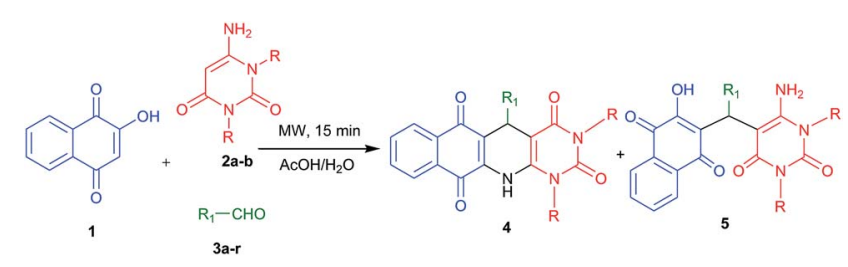

\begin{tabular}{|c|c|c|c|c|c|c|}
\hline \multirow{2}{*}{$\begin{array}{l}\text { Entry } \\
1\end{array}$} & \multirow{2}{*}{$\frac{\mathrm{R}}{\mathrm{CH}_{3}}$} & \multirow{2}{*}{$\begin{array}{l}\mathrm{R}_{1} \\
\mathrm{C}_{6} \mathrm{H}_{5}\end{array}$} & \multicolumn{2}{|c|}{$\begin{array}{l}\% \text { yield }^{b} \\
\text { of } 4\end{array}$} & \multicolumn{2}{|c|}{$\begin{array}{l}\% \text { yield } \\
\text { of } 5^{c}\end{array}$} \\
\hline & & & 4aa & 79 & $5 \mathbf{a a}$ & \\
\hline 2 & $\mathrm{CH}_{3}$ & $4-\mathrm{ClC}_{6} \mathrm{H}_{4}$ & $4 a b$ & 87 & $5 \mathbf{a b}$ & \\
\hline 3 & $\mathrm{CH}_{3}$ & $4-\mathrm{CH}_{3} \mathrm{C}_{6} \mathrm{H}_{4}$ & 4ac & 90 & $5 a c$ & 8 \\
\hline 4 & $\mathrm{CH}_{3}$ & $4-\mathrm{OCH}_{3} \mathrm{C}_{6} \mathrm{H}_{4}$ & 4ad & 85 & 5 ad & \\
\hline 5 & $\mathrm{CH}_{3}$ & $4-\mathrm{CH}\left(\mathrm{CH}_{3}\right)_{2} \mathrm{C}_{6} \mathrm{H}_{4}$ & 4ae & 82 & $5 a e$ & \\
\hline 6 & $\mathrm{CH}_{3}$ & $4-\mathrm{NO}_{2} \mathrm{C}_{6} \mathrm{H}_{4}$ & 4af & 64 & 5 af & \\
\hline 7 & $\mathrm{CH}_{3}$ & $4-\mathrm{FC}_{6} \mathrm{H}_{4}$ & $4 a g$ & 71 & $5 a g$ & \\
\hline 8 & $\mathrm{CH}_{3}$ & $2-\mathrm{ClC}_{6} \mathrm{H}_{4}$ & $4 \mathrm{ah}$ & 90 & $5 \mathbf{a h}$ & \\
\hline 9 & $\mathrm{CH}_{3}$ & $3-\mathrm{BrC}_{6} \mathrm{H}_{4}$ & 4ai & 78 & 5ai & \\
\hline 10 & $\mathrm{CH}_{3}$ & Naphthyl & 4aj & 85 & $5 a j$ & \\
\hline 11 & $\mathrm{CH}_{3}$ & $2-\mathrm{OCH}_{3} \mathrm{C}_{6} \mathrm{H}_{4}$ & 4ak & 92 & 5ak & \\
\hline 12 & $\mathrm{H}$ & $\mathrm{C}_{6} \mathrm{H}_{5}$ & $4 \mathbf{b a}$ & 89 & $5 \mathbf{b a}$ & \\
\hline 13 & $\mathrm{H}$ & $4-\mathrm{OCH}_{3} \mathrm{C}_{6} \mathrm{H}_{4}$ & $4 \mathrm{bd}$ & 91 & $5 b d$ & \\
\hline 14 & $\mathrm{H}$ & $4-\mathrm{CH}\left(\mathrm{CH}_{3}\right)_{2} \mathrm{C}_{6} \mathrm{H}_{4}$ & 4be & 87 & 5 be & \\
\hline 15 & $\mathrm{H}$ & $4-\mathrm{FC}_{6} \mathrm{H}_{4}$ & $4 \mathrm{bg}$ & 89 & $5 b g$ & \\
\hline 16 & $\mathrm{H}$ & $2-\mathrm{ClC}_{6} \mathrm{H}_{4}$ & $4 \mathrm{bh}$ & 87 & $5 \mathbf{b h}$ & \\
\hline 17 & $\mathrm{H}$ & $3-\mathrm{BrC}_{6} \mathrm{H}_{4}$ & $4 \mathbf{b i}$ & 92 & $5 \mathbf{b i}$ & \\
\hline 18 & $\mathrm{H}$ & $2-\mathrm{OCH}_{3} \mathrm{C}_{6} \mathrm{H}_{4}$ & $4 \mathbf{b k}$ & 96 & $5 \mathbf{b k}$ & \\
\hline 19 & $\mathrm{H}$ & $2-\mathrm{CH}_{3} \mathrm{C}_{6} \mathrm{H}_{4}$ & $4 \mathrm{bl}$ & 93 & $5 \mathrm{bl}$ & \\
\hline 20 & $\mathrm{H}$ & 2,6- $\mathrm{DiCH}_{3} \mathrm{C}_{6} \mathrm{H}_{3}$ & $4 \mathrm{bm}$ & 87 & 5 am & \\
\hline 21 & $\mathrm{H}$ & $4-\mathrm{BrC}_{6} \mathrm{H}_{4}$ & $4 \mathrm{bn}$ & 87 & $5 b n$ & \\
\hline 22 & $\mathrm{H}$ & 4- $\mathrm{CNC}_{6} \mathrm{H}_{4}$ & 4 bo & 78 & 5 bo & \\
\hline 23 & $\mathrm{CH}_{3}$ & Cyclohexyl & $4 a q$ & - & $5 a q$ & \\
\hline 24 & $\mathrm{CH}_{3}$ & Butyl & $4 a r$ & - & $5 \mathrm{ar}$ & \\
\hline
\end{tabular}

${ }^{a}$ Reactions were carried out in $1.0 \mathrm{mmol}$ scale with $1: 1: 1$ ratio of 2 hydroxy-1,4-naphthaquinone, 1,3-dimethyl-6-aminouracil and 4methylbenzaldehyde in acetic acid/water (1:1) in microwave. ${ }^{b}$ Isolated yields. ${ }^{c}$ For full characterization of compounds 5 , please see ref. 22.
Table 3 Scope of the reaction ${ }^{a}$

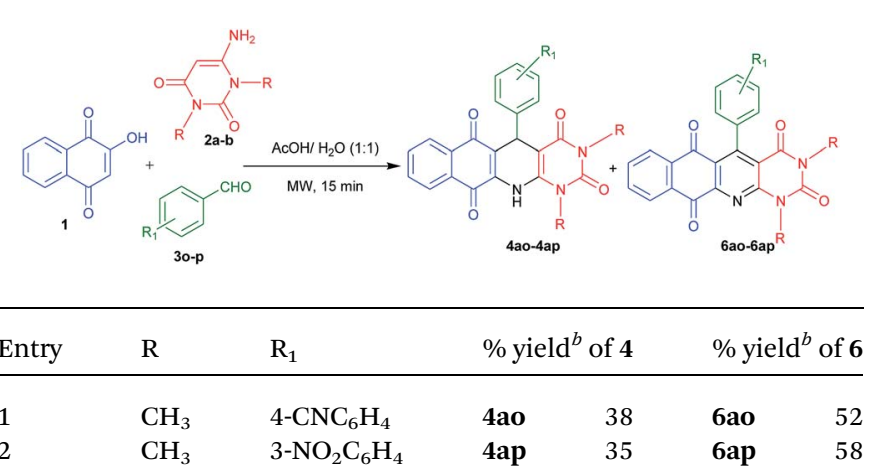

${ }^{a}$ Reactions were carried out with $1: 1: 1$ ratio of 2-hydroxy-1,4naphthaquinone, 1,3-dimethyl-6-aminouracil and 4methylbenzaldehyde in acetic acid/water $(1: 1)$ under microwave irradiation. ${ }^{b}$ Isolated yields.

summarized in Table 2. It is notable that the characteristics of 2a-b and 3a-r had an important influence on the final products. In most of the cases when 2a was employed, cyclic product 4 was obtained as major and acyclic product $\mathbf{5}$ as minor product (Table 2, entries 1-7 and 9). However, in the cases of 2-chlorobenzaldehyde $\mathbf{3 h}$, naphthaldehyde $\mathbf{3 j}$ and 2-methoxybenzaldehyde $3 \mathbf{k}$, we obtained exclusively cyclic product and

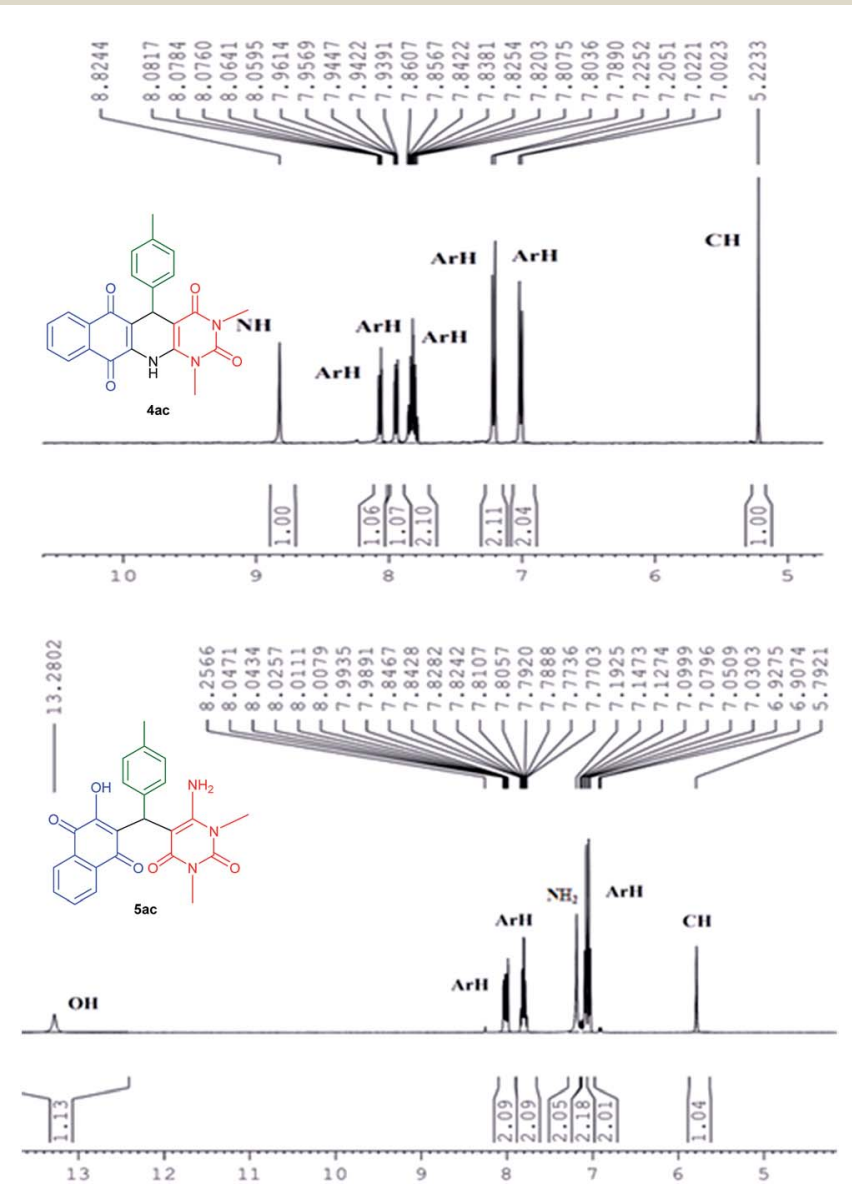

Fig. 3 Comparison of ${ }^{1} \mathrm{H}$ NMR spectra of cyclic product $4 \mathrm{ac}$ with acyclic product 5 ac. 
no acyclic product (Table 2, entries 8, 10 and 11) was observed. Further, when 6-aminouracil $\mathbf{2 b}$ was tested with $\mathbf{1}$ and different substituted aldehydes $\mathbf{3}(\mathbf{a}, \mathbf{d}-\mathbf{e}, \mathbf{g}-\mathbf{i}, \mathbf{k}-\mathbf{o})$ only cyclic products were observed (Table 2, entries 12-22). Next we examined some aliphatic aldehydes such as cyclohexyl carboxaldehyde $\mathbf{3 q}$ and butyraldehyde 3r. Unfortunately, they provided acyclic product only (Table 2, entries 23 and 24). However, when 4-cyanobenzaldehyde $3 \mathbf{o}$ and 3-nitrobenzaldehyde 3p were used, we obtained $6 \mathbf{a o}$ and 6ap along with 4 ao and 4ap (Table 3, entries 1 and 2) respectively.

All the products were fully characterized by IR, ${ }^{1} \mathrm{H}$ NMR, ${ }^{13} \mathrm{C}$ NMR spectroscopy as well as HRMS. The formation of $\mathbf{4}$ and $\mathbf{5}$ were ascertained from NMR spectroscopy with compound 4ac and 5ac (Fig. 3). As a representative case, ${ }^{1} \mathrm{H}$ NMR of 4ac was interpreted by the presence of a singlet at 8.82 for $-\mathrm{NH}$ proton, 8.08-7.00 ppm for eight Ar-H protons, and singlet at 5.22 for $\mathrm{CH}$ proton. While, ${ }^{1} \mathrm{H}$ NMR of 5ac was characterized by the presence of a singlet at 13.28 for $-\mathrm{OH}$ proton, 8.26-7.77 and 7.15-6.90 ppm for eight $\mathrm{Ar}-\mathrm{H}$ proton and two singlets at 7.19 and 5.79 for $-\mathrm{NH}_{2}$ and $-\mathrm{CH}$ protons respectively. From this it is clear that the product 4ac is the fused polycyclic N-heterocycle whereas the acyclic product is 5ac where free $-\mathrm{NH}_{2}$ and $-\mathrm{OH}$ groups are present.

The formation of product 4 , can be explained by the proposed mechanism, as shown in scheme 2. The reaction is initiated by a acetic acid assisted aldol condensation to provide A which transforms to $\mathbf{B}$ after elimination of water molecule. Then $\mathbf{B}$ reacts with 6-aminouracil derivatives $\mathbf{2 a - b}$ in a Michaeltype fashion and gave $\mathbf{C}$ which undergoes intramolecular condensation followed by tautomerization to give the corresponding product (4).

Next, we attempted to convert acyclic product which we obtained under reflux conditions to the corresponding cyclic products. For that we have treated the acyclic product 5ac in acetic acid/water (1:1) under MW heating for $15 \mathrm{~min}$ and the corresponding cyclic product 4 ac was obtained in $78 \%$ yield (Scheme 3).

Finally, we explored cinnamaldehyde an $\alpha, \beta$-unsaturated aldehyde in this three component reaction under the similar reaction conditions. To our surprise, this aldehyde did not provide expected acyclic product 5as or cyclic product 4as, instead of these a novel unexpected cyclic product 7as was obtained as shown in Scheme 4.

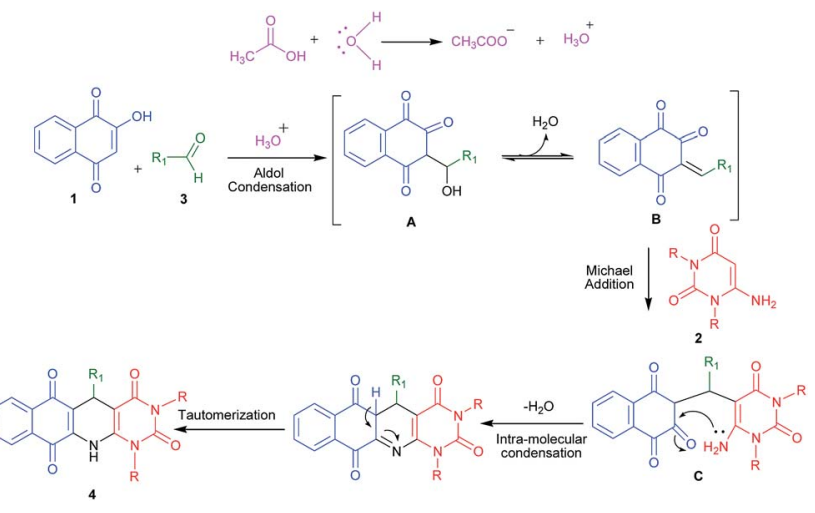

Scheme 2 Proposed mechanism.
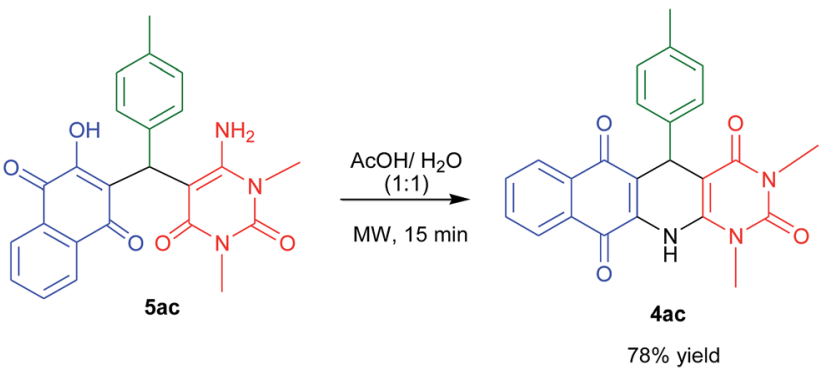

Scheme 3 Synthesis of cyclic product from the acyclic one.

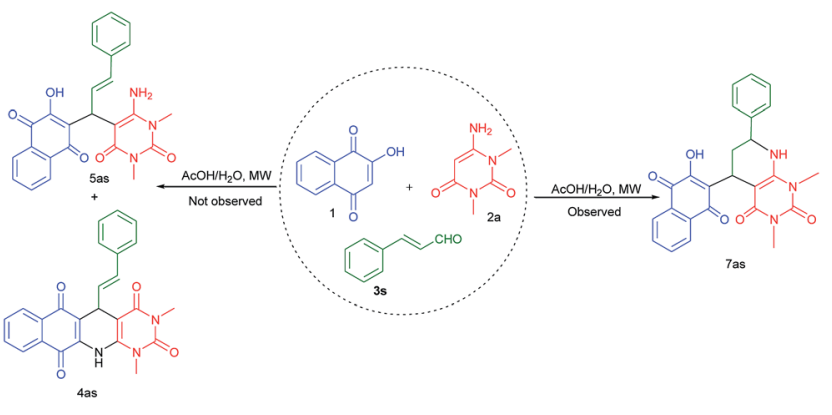

Scheme 4 Synthesis of unexpected product 7as from the reaction of cinnamaldehyde, 2-hydroxy-1,4-naphthaquinone and 2a.

\section{Conclusions}

In conclusion, we have demonstrated the effects of reaction conditions on the formation of two types of products from the three-component reaction of 2-hydroxy-1,4-naphthaquinone, aldehydes and 6-aminouracils. This method is a green tool for the synthesis of fused polycyclic N-heterocycles in acetic acid/ water under microwave heating. The main advantages of this method are (i) easy purification process of the products avoiding column chromatographic purification, (ii) high atom economy of the reaction (iii) use of water as solvent, (iv) short reaction time, (v) good yields of the products and (vi) environmentally benign procedures. Considering the presence of naphthaquinone and pyrimidine moiety fused with 1,4-DHPs, it is expected that these products will exhibit promising bioactivities.

\section{Acknowledgements}

We are grateful to NIT Patna and IIT Patna for providing general research facilities to carryout this work. T. P. is thankful to SERB-DST, India for financial support with Sanction No. EMR/ 2016/000960. The authors are also thankful to SAIF-Panjab University and SAIF-IIT Patna for providing the analytical facilities for characterization of products.

\section{Notes and references}

1 (a) I. Ugi, Pure Appl. Chem., 2001, 73, 187; (b) D. J. Ramon and M. Yus, Angew. Chem., Int. Ed., 2005, 44, 1602; (c) A. Dömling, Chem. Rev., 2006, 106, 17; (d) E. Ruijter and R. V. A. Orru, in Multicomponent Reactions in Organic Synthesis, ed. J. Zhu, Q. 
Wang and M.-X. Wang, Wiley-VCH, Weinheim, 2014, ch. 2, p. 13; (e) V. Nair, C. Rajesh, A. Vinod, U. S. Bindu, A. R. Streekenth, J. S. Mathen and L. Balagopal, Acc. Chem. Res., 2003, 36, 899.

2 (a) J. Gerencser, G. Dorman and F. Darvas, QSAR Comb. Sci., 2006, 25, 439; (b) R. V. A. Orru and M. de Greef, Synthesis, 2003, 10, 1471; (c) C. Hulme and V. Gore, Curr. Med. Chem., 2003, 10, 51; (d) B. E. Evans, K. E. Rittle, M. G. Bock, R. M. DiPardo, R. M Freidinger, W. L. Whitter, G. F. Lundell, D. F. Veber, P. S. Anderson, R. S. L. Chang, V. J. Lotti, D. J. Cerino, T. B. Chen, P. J. Kling, K. A. Kunkel, J. P. Springer and J. Hirshfield, J. Med. Chem., 1988, 31, 2235.

3 D. O'Hagan, Nat. Prod. Rep., 2000, 17, 435.

4 (a) S. Caddick and R. Fitzmaurice, Tetrahedron, 2009, 65, 3325; (b) C. O. Kappe, Angew. Chem., Int. Ed., 2004, 43, 6250; (c) D. Dallinger and C. O. Kappe, Chem. Rev., 2007, 107, 2563; (d) W. S. Chow and T. H. Chan, Tetrahedron Lett., 2009, 50, 1286.

5 (a) P. A. Grieco, Organic Synthesis In Water, Thomson Science, London, 1998, pp. 1-278; (b) R. Breslow and U. Maitra, Tetrahedron Lett., 1984, 25, 1239; (c) D. C. Rideout and R. Breslow, J. Am. Chem. Soc., 1980, 102, 7816; (d) S. Narayan, J. Muldoon, M. G. Finn, V. V. Fokin, H. C. Kolb and K. B. Sharpless, Angew. Chem., Int. Ed., 2005, 44, 3275.

6 B. Sharifzadeh, N. O. Mahmoodi, M. Mamaghani, K. Tabatabaeian, A. S. Chirani and I. Nikokar, Bioorg. Med. Chem. Lett., 2013, 23, 548.

7 (a) A. R. Katritzky, D. O. Tymoshenko, D. Monteux, V. Vvedensky, G. Nikonov, C. B. Cooper and M. Deshpande, J. Org. Chem., 2000, 65, 8059; (b) B. E. Maryanoff, D. F. McComsey, W. Ho, R. P. Shank and B. Dubinsky, Bioorg. Med. Chem. Lett., 1996, 6, 333; (c) A. B. Reitz, D. A. Gauthier, W. Ho and B. E. Maryanoff, Tetrahedron, 2000, 56, 8809; (d) S. M. Rida, F. S. G. Soliman, E. Badawey and T. Kappe, J. Heterocycl. Chem., 1988, 25, 1725; (e) S. M. Rida, F. S. G. Soliman, E. Badawey, E. El-Ghazzawi, O. Kader and T. Kappe, J. Heterocycl. Chem., 1988, 25, 1087; (f) E. Badawey and T. Kappe, Eur. J. Med. Chem., 1995, 30, 327; (g) S. A. M. ElHawash, E. Badawey and T. Kappe, Pharmazie, 1999, 54, 341. 8 (a) C. Ibis, A. F. Tuyun, H. Bahar, S. Sahinler Ayla, M. V. Stasevych, R. Y. Musyanovych, O. KomarovskaPorokhnyavets and V. P. Novikov, Med. Chem. Res., 2013, 22, 2879; (b) C. Ibis, A. F. Tuyun, H. Bahar, S. Sahinler Ayla, M. V. Stasevych, R. Y. Musyanovych, O. KomarovskaPorokhnyavets and V. P. Novikov, Med. Chem. Res., 2014, 23, 2140.

9 (a) Y. M. Kanaan, J. R. Das, O. Bakare, N. M. Enwerem, S. Berhe, D. Beyene, V. Williams, Y. Zhou and R. L. Copeland Jr, Anticancer Res., 2009, 1, 191; (b) N. M. Rahmoun, Z. Boucherit-Atmani, M. M. Benabdallah, K. Boucherit, D. Villemin and N. Choukchou-Braham, Am. J. Med. Biol. Res., 2013, 1, 16.

10 T. Kayashima, M. Mori, H. Yoshida, Y. Mizushina and K. Matsubara, Cancer Lett., 2009, 278, 34.
11 (a) H. Z. Si, T. Wang, K. J. Zhang, Z. D. Hu and B. T. Fan, Bioorg. Med. Chem., 2006, 14, 4834; (b) S. B. Sapkal, K. F. Shelke, B. B. Shingate and M. S. Shingare, Tetrahedron Lett., 2009, 50, 1754; (c) T. Yamamoto, S. Niwa, M. Tokumasu, T. Onishi, S. Ohno, M. Hagihara, H. Koganei, S. Fujita, T. Takeda, Y. Saitou, S. Iwayama, A. Takahara, S. Iwata and M. Shoji, Bioorg. Med. Chem. Lett., 2012, 22, 3639.

12 (a) A. M. Vijesh, A. M. Isloor, S. K. Peethambar, K. N. Shivananda, T. Arulmoli and N. A. Isloor, Eur. J. Med. Chem., 2011, 46, 5591; (b) G. Sabitha, G. S. K. K. Reddy, C. S. Reddy and J. S. Yadav, Tetrahedron Lett., 2003, 44, 4129; (c) N. Tewari, N. Dwivedi and R. P. Tripathi, Tetrahedron Lett., 2004, 45, 9011; (d) A. R. Trivedi, D. K. Dodiya, B. H. Dholariya, V. B. Kataria, V. R. Bhuva and V. H. Shah, Bioorg. Med. Chem. Lett., 2011, 21, 5181.

13 (a) B. Desai, D. Sureja, Y. Naliapara, A. Shah and A. Saxena, Bioorg. Med. Chem., 2001, 9, 1993; (b) P. S. Kharkar, B. Desai, H. Gaveria, B. Varu, R. Loriya, Y. Naliapara, A. Shah and V. M. Kulkarni, J. Med. Chem., 2002, 45, 4858; (c) B. R. Prashantha, M. Kumar, E. Pankaj, A. Karthikeyan, S. Bansal and P. Vijayan, Med. Chem. Res., 2010, 19, 344.

14 (a) N. Fujiwara, T. Nakajima, Y. Ueda, H. K. Fujita and H. Awakami, Bioorg. Med. Chem., 2008, 16, 9804; (b) L. Ballell, R. A. Field, G. A. C. Chung and R. J. Young, Bioorg. Med. Chem. Lett., 2007, 17, 1736; (c) E. Wagner, K. Al-Kadasi, M. Zimecki and W. Sawka-Dobrowolska, Eur. J. Med. Chem., 2008, 43, 2498.

15 (a) R. Leon, C. Rios, J. Maro-Contelles, O. Huertas, X. Barril, F. J. Luque, M. G. Lopez, A. G. Garcia and M. Villarroya, Bioorg. Med. Chem., 2008, 16, 7759; (b) J. Marco-Contelles, R. Leon, C. Rios, A. Samadi, V. Andrisano, O. Huertas, X. Barril, F. J. Luque, M. I. Rodriguez-Franco, B. Lopez, M. G. Lopez, A. G. Garcia, M. C. Carreiras and M. Villarroya, J. Med. Chem., 2009, 52, 2724.

16 M. B. El-Ashmawy, M. A. El-Sherbeny and N. S. El-Gohary, Med. Chem. Res., 2013, 22, 2724.

17 H.-A. S. Abbas, H. N. Hafez and A.-R. B. A. El-Gazzar, Eur. J. Med. Chem., 2011, 46, 21.

18 (a) A. Y. Kots, B.-K. Choi, M. E. Estrella-Jimenez, C. A. Warren, S. R. Gilbertson, R. L. Guerrant and F. Murad, Proc. Natl. Acad. Sci. U. S. A., 2008, 105, 8440; (b) E. A. Tanifum, A. Y. Kots, B.-K. Choi, F. Murad and S. R. Gibertson, Bioorg. Med. Chem. Lett., 2009, 19, 3067; (c) A. A. Toropov, A. P. Toropova, E. Benfenati, G. Gini, D. Leszczynska, J. Leszczynski and G. De Nucci, Biochem. Biophys. Res. Commun., 2013, 432, 214.

19 (a) V. K. Tandon and S. Kumar, Expert Opin. Ther. Pat., 2013, 23, 1087; (b) S. G. McNaughton, B. A. Estevez, A. S. Jimenez, R. A. D. Gutierrez, P. L. Fernandez, C. Diaz and N. Bonifacio, WO 2014016314 A1 20140130, PCT Int. Appl. 2014.

20 G. M. Ziarani, N. H. Nasab and N. Lashgari, RSC Adv., 2016, 6, 38827.

21 (a) I. R. Siddiqui, P. Rai, Rahila, H. Sagir and P. Sing, $R S C$ Adv., 2015, 5, 27603; (b) J. Azizian, A. S. Delbari and K. Yadollahzadeh, Synth. Commun., 2014, 44, 3277; (c) 
B.-X. Du, B. Zhao, G. Cai, Y.-L. Li and X.-S. Wang, J. Chem. Res., 2012, 36, 453.

22 R. Bharti and T. Parvin, RSC Adv., 2015, 5, 66833.

23 (a) R. Bharti and T. Parvin, Mol. Diversity, 2016, 20, 867; (b) R. Bharti and T. Parvin, Synth. Commun., 2015, 45, 1442; (c) R. Bharti and T. Parvin, J. Heterocycl. Chem., 2015, 52, 1806.
24 (a) S. Karamthulla, S. Pal, T. Parvin and L. H. Choudhury, $R S C$ Adv., 2014, 4, 15319; (b) S. Pal, T. Parvin and L. H. Choudhury, Mol. Diversity, 2012, 16, 129; (c) A. T. Khan, T. Parvin and L. H. Choudhury, J. Org. Chem., 2008, 73, 8398. 